\title{
THE ROLE OF CHOLINERGIC INSUFFICIENCY IN COGNITIVE IMPAIRMENT AMONG PATIENTS WITH CHRONIC CEREBRAL ISCHEMIA
}

DOI: 10.36740/WLek202005104

\author{
Tatiana V. Chernii \\ STATE INSTITUTION OF SCIENCE «RESEARCH AND PRACTICAL CENTER OF PREVENTIVE AND CLINICAL MEDICINE» STATE ADMINISTRATIVE DEPARTMENT, \\ KYIV, UKRAINE
}

\begin{abstract}
The aim: A correction of cholinergic insufficiency for the treatment of cognitive impairment in chronic brain ischemia.

Materials and methods: In the period 2014 - 2017, 88 people aged 40 to 68 years were comprehensively examined in dynamics. Patients were divided into three groups, statistically comparable to the main disease - $\mathrm{C}(\mathrm{C} 2$ degrees, gender and age. In addition to the protocol, patients with discirculatory encephalopathy of all the investigated groups received a complex of drugs aimed at correcting neurotransmitter metabolism.

Results: The statistically significant manifestations of the recovery of cognitive function (according to the MMSE scale) after the application of the developed complex therapy were associated mainly with a decrease in impulsivity due to an increase in the level of attention. The statistically significant manifestations of a decrease in the level of anxietydepressive disorders (according to the DASS-21 scale) after the application of the developed complex therapy were associated mainly with a decrease in anxiety due to the restoration of neurohumoral balance.

Conclusions: The inclusion in the treatment protocol for CCl complex of drugs aimed at eliminating cholinergic deficiency, acetylcholinesterase inhibitors in combination with choline precursors, leads to the correction of cognitive impairment in chronic brain ischemia.
\end{abstract}

KEY WORDS: chronic cerebral ischemia, MMSE score, DASS-21 scale, cholinergic insufficiency

Wiad Lek. 2020;73(5):857-863

\section{INTRODUCTION}

Chronic cerebral ischemia (CCI) is slowly progressive dysfunction arising as a result of diffuse or intermediate brain tissue's damage in conditions of long-standing cerebral circulatory supply insufficiency. The term "chronic cerebral ischemia" was proposed by the International Classification of Diseases, $10^{\text {th }}$ Revision (ICD-10) instead of the previously used term "discirculatory encephalopathy" [1]. The term "mild cognitive impairment" is also found in the literature (English: mild cognitive impairment, MCI) [2].

It has been proven that the mechanisms of brain aging are mostly determined by changes in neurotransmitter systems [3].Age-related disorders of neurotransmitter metabolism are not total and unidirectional, but they can occur in a defined parts of transmitter systems, which expressed in a different degrees and also have the polymodal mechanisms [3].

It has been proven that underlies of the cognitive impairment in cerebral insufficiency is cholinergic insufficiency, caused by decreasing in acetylcholine production, loss of cholinergic neurons. Assessment of the cholinergic mechanisms' importans for human cognitive ability is connected with an analysis of the architectonics of projection track, receptors and synapses, the mediator of which is an acetylcholine[4]. Cholinergic fibers are sent to all layers of the cerebral cortex, but the highest density of cholinergic fibers is found in the first and the second layers of the cortex, as well as in the upper part of the third layer. Thus muscarine receptorsprovide disinhibition of the pyramidal layer of the cortex and enhance the exchange of information between the layers of the cortex [4].

The key role in providing memory and cognition is played by the hippocampus, in which were identified terminals and various types of specific receptors with containing of acetylcholinesterase ( $\mathrm{M}$ - and $\mathrm{H}$-cholinergic receptors) detected at lower density of cholinergic neurons proper [5]. Cholinergic neurons are also involved in intra-internal integration processes and the implementation of the psychomotor functions of the nucleus. Efferent cholinergic neurons of the striate body carrying out a filtration sensory afferentation to the cortex, playing an exceptional role in attention processes [5].

There are two classes of drugs aimed at overcoming cholinergic deficiency: 1)preparations precursors as a choline: choline acetyl transferase ( $\alpha$-GPC) and cytidine 5 '-diphosphocholine sodium; 2) acetylcholinesterase inhibitors: ipidacrine, donepezil, rivastigmine, galantamine, etc. [6].

Citicoline (cytidine-5-diphosphocholine) is an indispensable precursor of phosphatidylcholine (lecithin), the main phospholipid of the all cell membranes, including 
Table I. Characteristics of patients with chronic ischemia of the brain in the three group research

\begin{tabular}{|c|c|c|c|c|c|}
\hline \multirow{2}{*}{ Characteristics of patients/data } & $1^{\text {st }}$ group & $2^{\text {nd }}$ group & $3^{\text {rd }}$ group & Total & \multirow{3}{*}{$\begin{array}{c}\text { Criterion } \\
\mathrm{X}^{2}\end{array}$} \\
\hline & \multicolumn{4}{|c|}{ Amount n; Me\% ( $\pm \mathrm{Cl} 95 \%) \% *$} & \\
\hline Number of patients & $28 ; 100 \%$ & $39 ; 100 \%$ & $21 ; 100 \%$ & $88 ; 100 \%$ & \\
\hline Men & $\begin{array}{c}8 ; 28,6 \% \\
(13,7-46,4) \% \text { * }\end{array}$ & $\begin{array}{c}13 ; 33,3 \% \\
(19,6-48,7) \% *\end{array}$ & $\begin{array}{c}8 ; 38,1 \% \\
(19-59,3) \% \text { * }\end{array}$ & $\begin{array}{c}29 ; 33 \% \\
(23,6-43,1) \% \text { * }\end{array}$ & $p=0,920$ \\
\hline Women & $\begin{array}{c}20 ; 71,4 \% \\
(53,6-86,3) \% \text { * } \\
\end{array}$ & $\begin{array}{c}26 ; 66,7 \% \\
(51,3-80,4) \% *\end{array}$ & $\begin{array}{c}13 ; 61,9 \% \\
(40,7-81) \% * \\
\end{array}$ & $\begin{array}{c}59 ; 67 \% \\
(56,9-76,4) \% \text { * }\end{array}$ & $p=0,920$ \\
\hline $\begin{array}{c}\text { Age years } \\
\text { Me }( \pm 95 \% \mathrm{Cl})\end{array}$ & $\begin{array}{c}59 \\
(56-68) \% \text { * }\end{array}$ & $\begin{array}{c}61 \\
(54-72) \% \text { * }\end{array}$ & $\begin{array}{c}58 \\
(56-70) \text { \% * }\end{array}$ & $\begin{array}{c}58 \\
(54-72) \% \text { * }\end{array}$ & $p=0,920$ \\
\hline
\end{tabular}

Notes: ${ }^{*}$ - determining confidence interval fraction (\% Cl) Fischer angular transformation, the integrated score Maraskuilo-Lyaha_Guryanova procedure for multiple comparisons fraction; 123 - statistically significant differences $(p \leq 0.05)$ in the 1st, 2nd, 3rd groups according to the Kruskalo-Wallis criterion.

neuronal membranes, increases the activity of the ascending reticular formation, which improves the production of dopamine in the brain, restores the balance of dopaminergic and cholinergic neurons in the region, improves the blood circulation brain stem and processes of utilization of oxygen and glucose in the tissues of the brain [7].

Choline alfoscerate (L-alpha glycerylphosphorylcholine- $\alpha-\mathrm{GPC}$ ) is a cholinomimetic with a primary effect on the central nervous system; it contains of $40.5 \%$ metabolically protected choline [8]. Metabolic defense provides the release of choline in the brain. According to meta-analyzes of choline, alpha phosphate is a highly effective medicine for cognitive dysfunction, which has the largest evidence base for all choline precursors [8].

As we analysethe mechanisms of the neuroprotective effect of choline precursors in acute cerebral ischemia, the authorspoint to the preferential effects of citicoline (direct reparation of neuronal membranes, a decrease in the degeneration of free fatty acids) and the preferential effects of choline alfoscerate (increasing the production of the neurotransmitter acetylcholine, the release of acetylcholine from the terminals in response to drug treatments (dose-dependent effect)) [8.9]. The main difference is that one non-energy-consuming reaction separates alfoscerate from choline choline, while the citicolineseparates five energy-consuming ones.

Ipidacrine, 4- Aminopyridinederivates- is a representative of anticholinesterase drug, which has a peripheric and central effects. In a basis of combined action of ipidacrine are two molecular mechanisms: 1) the block of potassium channels of the membrane of neurons and muscle cells; 2 ) the invertible inhibition of cholinesterase (acetylcholinesterase and butyrylcholinesterase) in synapses.

The main features of ipidacrine action: dose-dependent peripheric and central effect, rapid entry into the brain, accumulation mainly in the cerebral cortex and the hippocampus, a large wide of therapeutic effect, low ability to lead a treatment tolerance with repeated prescription, a good tolerance [10].Comparing the effects of ipidacrine and choline alfoscerate, researchers consider that they are synergists, medicine that accelerate the exit from coma and the subsequent restoration of the mental activity of patients $[8,10]$. Ipidacrine has nootropic, mnemotropic, psychostimulating, antiasthenic and antidepressant effects. These properties of ipidacrine are associated with the ability to increase the content of BDNF in blood serum, stimulate adaptive neuroplasticity, modulating the diaschisisand neuroprotective effect in relation to cholinergic neurons [11].

Our results of researching EEG predictors of neurotransmitter and neuroglial activity in patients with chronic brain ischemia indicate a serious dysfunction of these systems: a significant increase in neuroglial, glutamatergic and adrenergic activity with a parallel decrease in cholinergic and dopaminergic activity [12].

\section{THE AIM}

A correction of cholinergic insufficiency for the treatment of cognitive impairment in chronic brain ischemia.

\section{MATERIALS AND METHODS}

In the period $2014-2017,88$ people aged 40 to 68 years were comprehensively examined in dynamics. Patients were divided into three groups, statistically comparable to the main disease - CCI 2 degrees, gender and age. The first group consisted of 28 patients with CCI 2 degrees without concomitant hypertension, the second consists of 39 patients with CCI 2 degrees with concomitant hypertension, and the third -21 patients with CCI 2 degrees and a history of stroke. 11 patients have a ischemic stroke, which developed mainly against the background of arterial hypertension, 10 patients - mainly against the background of arterial hypertension and cerebral atherosclerosis. Among the examined patients were 29 men and 59 women. The control group of healthy volunteers consisted of 20 people (7 men and 13 women) (Table I).

The clinical form of chronic ischemic cerebrovascular disease and arterial hypertension was diagnosed on the basic criteria $[13,14]$.In order to establish the stage of hypertension in the classification of end-organ damage. The diagnosis was confirmed by general clinical, clinical and neurological, laboratory, instrumental examination, neuropsychological testing. Clinical and laboratory research had included a general blood test, a biochemical blood test, and a lipid profile. Clinical and instrumental examination 
methods had included computed tomography, electrocardiography, measurement of blood pressure and heart rate. Duplex scanning of extra- and intracranial vessels of the brain was carried out with the help of stenosis and deformation of the vessels of the head and neck, their hemodynamic significance, thickness and uniformity of the intima-media complex, and the presence of atherosclerotic changes were identified. To evaluate the patients' cognitive functions, a short scale for assessing the mental status of MMSE was used - Mini-mental State Examination (determining orientation in time and place, state of short-term, long-term memory, language function, gnosis, praxis) [12]. According to MMSE, 29-30 points were evaluated as the absence of cognitive impairment, $27-28$ points - mild cognitive impairment, 24-26 - moderate cognitive impairment, 20-23 points - the initial stage of dementia, $<20$ - expressed stages of dementia. Anxiety and depression were researched using the scale "Depression, Anxiety, Stress" (Depression Anxiety Stress Scales (DASS-21)) [12].The results of the survey determined normal, mild, moderate, strong and very strong degrees of depression, anxiety and stress. Investigations were conducted in the dynamics of treatment.

Criteria of patients' inclusion in the researching: men and women of working age, civil servants with CCI 2 grade, aged 40 to 68 years, without CCI, with CCI, patients with chronic chemotherapy, who have had an acute ischemic stroke with a diagnosis confirmed by neuroimaging data and neurological findings deficiency (mild mono- or hemiparesis, vestibular disorders, speech impairment, optical disorders, emotional-volitional and psycho-organic disorders) against a background of arterial hypertension. According to the anamnestic and clinical data, patients were comparable in age and severity of neurological deficit after suffering an IS (from 5 to 9 points on the NIHSS scale, an average of $7.2 \pm 0.15$ points). Protocol of consent to the study. The study was carried out in compliance with the basic provisions of the GCP (Strasbourg, 24.11.1996), in accordance with the requirements of the Council of Europe Convention on the Protection of Human Rights in Biomedicine (1997), the Declaration of Helsinki of the World Medical Association for Human Research (19642000). The Commission on Bioethics of State Scientific Institution "Scientific and Practical Center for Preventive and Clinical Medicine" of the State Administrative Department approved that the conducted clinical and experimental studies do not contradict the basic bioethical standards (protocol N 11 of January 25, 2014).

Criteria of patients' exclusion in the researching: patients with severe somatic pathology, clinically significant vascular events and a history of traumatic brain injury. According to neuroimaging data patients with hemorrhagic stroke, patients with severe motor impairment, patients with uncompensated diabetes mellitus, the onset of uncompensated diseases, alcohol and drug abuse.

According to existing protocols all patients were prescribed pathogenetic therapy [18].

In addition to the protocol, patients with discirculatory encephalopathy of all the investigated groups received a complex of drugs aimed at correcting neurotransmitter metabolism: in the morning $1 \mathrm{ml}(15 \mathrm{mg})$ of the solution of ipidacrine hydrochloride monohydrate intramuscularly 1 time per day for 14 days. In 1-2 hours after the introduction of ipidacrine, $4 \mathrm{ml}(1000 \mathrm{mg})$ of choline alfoscerate solution and $4 \mathrm{ml}(1000 \mathrm{mg})$ of citicoline solution were intravenous drip-feed once a day for 14 days.

When prescribing carefully analyzed ipidacrine contraindications and possible side effects: hypersensitivity to ipidacrine, epilepsy, extrapyramidal disorders with hyperkinesis, angina pectoris, severe bradycardia, bronchial asthma, vestibular disorders, mechanical obstruction of the intestines and urinary tract, gastric or duodenal ulcer in the acute stage.

As contraindications to use of choline alphosceratus and possible side effects were considered: known hypersensitivity to the drug. Concurrent reactions: it may occur a nausea (which is mainly the result of secondary dopaminergic activation), abdominal pain and short-term confusion is rarely. In this case, it is necessary to reduce the dose of medicine.

As contraindications to use citicoline and possible concurrent reactions were considered: hypersensitivity to the drug, increased tone of the parasympathetic nervous system, concurrent reactions: from the central and peripheral nervous system (severe headache, vertigo, hallucinations), from the cardiovascular system ( arterial hypertension, arterial hypotension, tachycardia) from the respiratory system (shortness of breath), from the digestive system (nausea, vomiting, diarrhea), from the immune side second system (allergic reaction, including: rash, flushing, rash, urticaria, purpura, pruritus, angioedema, anaphylactic shock), general reactions (chills).

None of the patients during the treatment had shown symptoms of an overdose of cholinergic drugs: bronchospasm, lacrimation, increased sweating, narrowing of the pupils, nystagmus, increased gastrointestinal motility, spontaneous defecation and urination, vomiting, jaundice, bradycardia, intracardiac arrhythmias, decreased blood pressure, anxiety, worries, excitation, a sense of fear, ataxia, cramps, coma, speech impairment, drowsiness, general weakness.

Statistical processing of the research results was carried out on a PC using the Microsoft Excel software package. Mathematical processing was performed using standard statistical packages STATISTICA 6.0.) [15].

\section{RESULTS}

As a result of a neurological examination of the investigated patients, among all neurological disorders coordinating disorders and pyramidal insufficiency prevailed - in patients of the 1st group $43.3 \%$ and $23.3 \%$, in patients of the 2nd group $33.3 \%$ and $11.1 \%$, accordingly. In patients of group 3, cognitive (77\%) and emotional (77\%) disorders were more often detected.

According to the results of evaluating the subjective and objective neurological symptoms in patients of the first group, cephalic, $56.6 \%$ vestibular, $30 \%$ cerebrosthenic, 


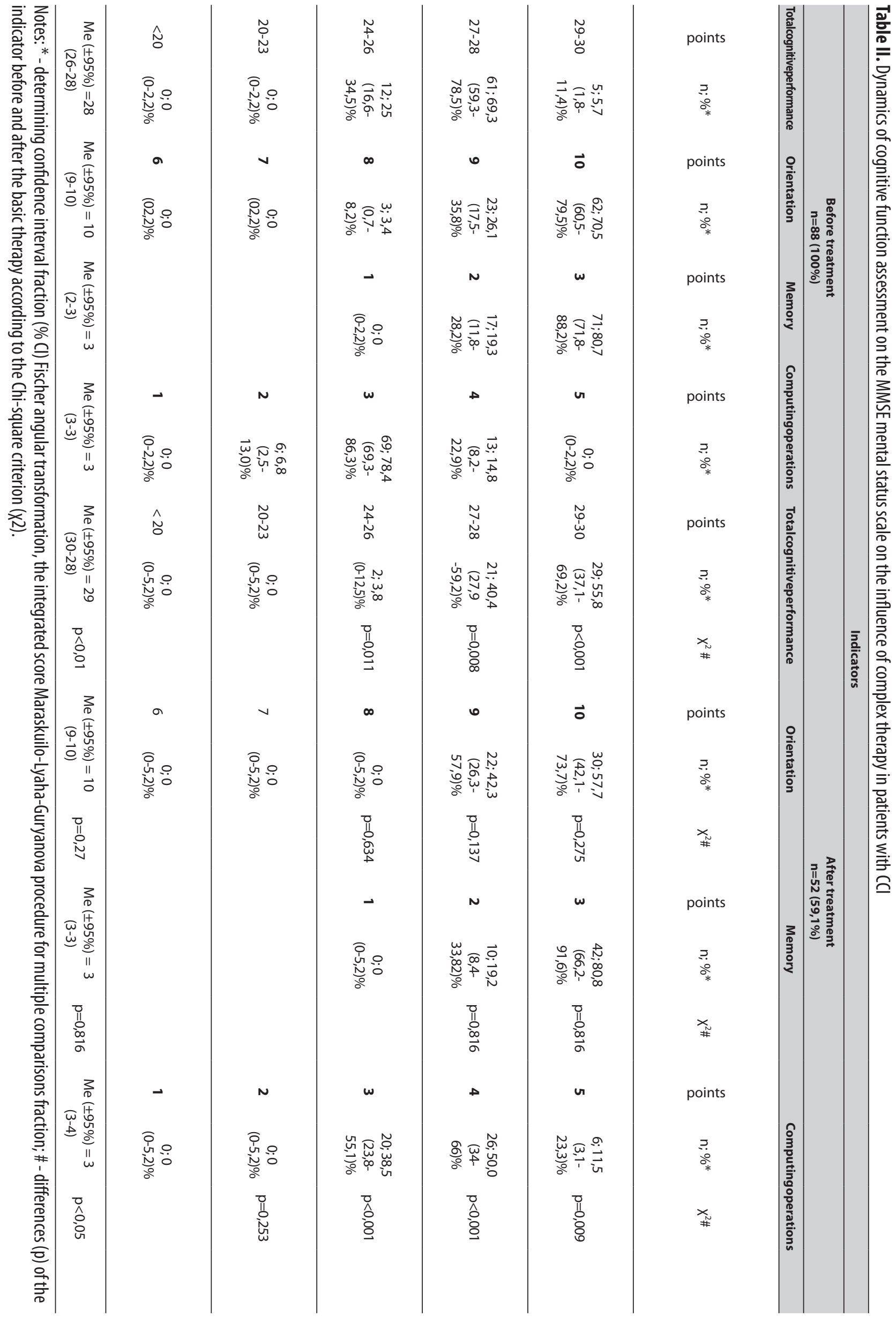


Table III. Dynamics of the assessment of anxiety-depressive disorders according to the DASS-21 scale under the influence of complex therapy in patients with chronic cerebral ischemia

\begin{tabular}{|c|c|c|c|c|c|c|c|c|c|c|c|c|c|c|}
\hline \multicolumn{15}{|c|}{ Indicators } \\
\hline \multicolumn{6}{|c|}{ Before treatment $n=88(100 \%)$} & \multicolumn{9}{|c|}{ After treatment $n=52(59,1 \%)$} \\
\hline \multicolumn{2}{|c|}{$\begin{array}{c}\text { A level } \\
\text { of depression }\end{array}$} & \multicolumn{2}{|c|}{$\begin{array}{c}\text { A level } \\
\text { of anxiety }\end{array}$} & \multicolumn{2}{|c|}{$\begin{array}{l}\text { A level } \\
\text { of stress }\end{array}$} & \multicolumn{3}{|c|}{$\begin{array}{c}\text { A level } \\
\text { of depression }\end{array}$} & \multicolumn{3}{|c|}{$\begin{array}{c}\text { A level } \\
\text { of anxiety }\end{array}$} & \multicolumn{3}{|c|}{$\begin{array}{l}\text { A level } \\
\text { of stress }\end{array}$} \\
\hline 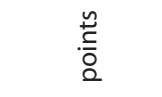 & $\mathrm{n} ; \% *$ & $\stackrel{\mathscr{n}}{\stackrel{\check{z}}{0}}$ & $\mathrm{n} ; \% *$ & $\stackrel{\stackrel{n}{\check{L}}}{\frac{0}{2}}$ & $\mathrm{n} ; \% *$ & 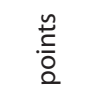 & $\mathrm{n} ; \% *$ & $x^{2} \#$ & $\begin{array}{l}\stackrel{n}{\bar{z}} \\
\stackrel{0}{2}\end{array}$ & $\mathrm{n} ; \% *$ & $x^{2} \#$ & 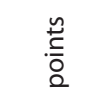 & $\mathrm{n} ; \%^{*}$ & $x^{2} \#$ \\
\hline $0-9$ & $\begin{array}{c}69 ; 78,4 \\
(69,3- \\
86,3) \%\end{array}$ & $0-7$ & $\begin{array}{c}15 ; 17 \\
(10- \\
25,6) \%\end{array}$ & $0-14$ & $\begin{array}{c}84 ; 95,5 \\
(90,1- \\
98,8) \%\end{array}$ & $0-9$ & $\begin{array}{c}48 ; 92,3 \\
(80,6- \\
98,3) \%\end{array}$ & $p=0,135$ & $0-7$ & $\begin{array}{c}33 ; 63,5 \\
(47,7- \\
78,6) \%\end{array}$ & $p<0,001$ & $0-14$ & $\begin{array}{c}51 ; 98,1 \\
(89,5- \\
100) \%\end{array}$ & $p=0,962$ \\
\hline $10-13$ & $\begin{array}{c}19 ; 21.6 \\
(13,7- \\
30,7) \%\end{array}$ & $8-9$ & $\begin{array}{c}62 ; 70,5 \\
(60,5- \\
79,5) \%\end{array}$ & $15-18$ & $\begin{array}{c}4 ; 4,5 \\
(1,2- \\
9,9) \%\end{array}$ & $10-13$ & $\begin{array}{c}4 ; 7,8 \\
(1,7- \\
19,4) \%\end{array}$ & $p=0,135$ & $8-9$ & $\begin{array}{c}19 ; 36,5 \\
(21,4- \\
52,3) \%\end{array}$ & $p<0,001$ & $15-18$ & $\begin{array}{c}1 ; 1,9 \\
(0- \\
10,5) \%\end{array}$ & $p=0,962$ \\
\hline $14-20$ & $\begin{array}{c}0 ; 0 \\
(0- \\
2,2) \%\end{array}$ & $10-14$ & $\begin{array}{c}11 ; 12,5 \\
(6,5- \\
20,2) \%\end{array}$ & 19-25 & $\begin{array}{c}0 ; 0 \\
(0- \\
2,2) \%\end{array}$ & $14-20$ & $\begin{array}{c}0 ; 0 \\
(0- \\
5,2) \%\end{array}$ & $p=0,951$ & $10-14$ & $\begin{array}{c}0 ; 0 \\
(0- \\
5,2) \%\end{array}$ & $p=0,061$ & $19-25$ & $\begin{array}{c}0 ; 0 \\
(0- \\
5,2) \%\end{array}$ & \\
\hline $\begin{array}{c}\mathrm{Me}( \pm 95 \%)=9 \\
(8-10)\end{array}$ & & $\begin{array}{l}( \pm 95 \%) \\
(7-10)\end{array}$ & & $\begin{array}{r}\mathrm{Me}( \pm 9 \\
(9\end{array}$ & $\begin{array}{l}5 \%)=11 \\
14)\end{array}$ & $\begin{array}{r}\mathrm{Me}( \pm 9 \\
(8\end{array}$ & $\begin{array}{l}5 \%)=9 \\
-9)\end{array}$ & $P=0,135$ & $\mathrm{Me}( \pm$ & $\begin{array}{l}75 \%)=8 \\
7-9)\end{array}$ & $p=0,05$ & $\begin{array}{r}\mathrm{Me}( \pm 9 \\
(9\end{array}$ & $\begin{array}{l}\text { 5\%) }=10 \\
14)\end{array}$ & $p=0,962$ \\
\hline
\end{tabular}

Notes: ${ }^{*}$ - determining confidence interval fraction (\% Cl) Fischer angular transformation, the integrated score Maraskuilo-Lyaha-Guryanova procedure for multiple comparisons fraction; \# - differences ( $p$ ) of the indicator before and after the basic therapy according to the Chi-square criterion (X2).

$26.6 \%$ mnestic syndromes were found in $63.3 \%$ and anxiety-depressive disorders were observed.

Among patients of the second group, cephalic, $44.4 \%$ vestibular, $47.2 \%$ cerebrosthenic, $17 \%$ mnestic syndromes were found in $63.9 \%$, anxiety-depressive disorders were observed in $22.2 \%$ and pyramidal insufficiency.

Among patients of the third group who had an ischemic stroke on the background of arterial hypertension, or a combination of arterial hypertension and cerebral atherosclerosis, vestibulo-atactic syndrome (68.2\%), cephalgic (72.7\%), cerebrosthenic (91\%), mnestic $(81.8 \%)$ and anxiety depressive disorders were observed (77.3\%).

After conducting a neuropsychological test on the MMSE scale, $46.6 \%$ of patients of the first group, $55 \%$ of patients of the second group and $52 \%$ of patients of the third group were found to have cognitive impairment.

A reliable difference in DASS-21 score in all the investigated groups was observed in the researching of anxiety ( $\mathrm{p}<0.001$ according to Wilcoxon $\mathrm{W}$-test $(\mathrm{W}-\mathrm{W}), \mathrm{p}$ $<0.05$, Kruskalo-Wallis test (kKU)) and depression level $(\mathrm{p}<0.033 \mathrm{~W}-\mathrm{W})$. The maximum subjective indicators of anxiety and depression were characteristic of the second group patients.

Self-assessment of cognitive abilities on the part of the patient should be considered, taking into account the fact that cognitive disorders are often accompanied by a decrease in criticism [12].
The prevalence of anxiety-depressive disorders (on the DASS-21 scale) of the second group patients and at least 3 groups is associated with more pronounced violations of criticism and memory impairment to patients of the first group.

A significant decrease in memory level (MMSE scale) of the first group patients to compare with the second group patients was mainly associated with impaired self-reproduction of information, which manifested itself in operational activities and training, while the memory of lifespin events basically remained intact. Such modal-nonspecific mnestic disorders with primary short-term memory disorders, combined with fatigue and emotional instability, indicate damage to the median nonspecific brain structures at the level of the lower parts of the brain stem (1st functional block of the brain according to A.R. Luria).

After a 4-5 week course of therapy with basic treatment using medicint of ipidacrine, choline alfoscerate, citicoline, we recorded the following changes in neuropsychological parameters on the MMSE and DASS-21 scales (Table. II and Table. III).

Significantly $(\mathrm{p}<0.001)$ the proportion of patients with a lack of pathological cognitive productivity increased (2930 points on the MMSE scale) and decreased $(\mathrm{p}<0.01)$ to compare the proportion of patients with mild cognitive impairment (28 to 24 points on the MMSE scale) (table 
II). First of all, the possibilities for more accurate counting operations expanded: statistically increased $(\mathrm{p}<0.01)$ the number of subjects able to correct 4 or 5 consecutive subtractions, and decreased $(\mathrm{p}<0.001)$ the proportion of those patients who were able to correctly 3 or less consecutive counting operations.

\section{DISCUSSION}

We can assume that the disturbance of the counting operations, recorded initially, are not associated with organic changes in the frontal lobes of the brain (primary and secondary "frontal acalculia"), but depend on the defeat of the basal and medio-basal parts of the frontal lobes of the brain (limbic-hippocampal system), which asknown, leads to significant changes in the emotional sphere of patient behavior [16]. Defects of this type of intellectual activity - counting operations - in our group of patients arise on the basis of impulsivity and manifest violation of the orienting basis of action at the expense of attention. There could be mistakes due to the acceleration of the flow of nervous and mental processes of defects in inhibitory processes and cholinergic dysregulation [17].

Changes after the treatment were registered using self-assessment on the DASS-21 scale, they were minimal and were manifested only in a decrease in the level of anxiety (Table 3.). There was a statistically significant increase ( $\mathrm{p}$ $<0.001)$ in the proportion of subjects without anxiety $(0-7$ points according to DASS-21) with a significant decrease $(\mathrm{p}<0.001)$ in the number of patients with mild anxiety disorders (8-9 points according to DASS-21). It should be noted that after the course of therapy, not a single patient was recorded with moderate disturbing changes (10-14 points according to DASS-21), while during the initial examination of such patients there were more than $12 \%$ (12.5 (6.5-20.2)\%, table 3.). Such changes in the level of anxiety should probably be associated with the restoration of neurohumoral balance after treatment: GABAergic inhibitory effects, serotonin-, catecholamine - peptidergic activation systems $[16,17]$.

\section{CONCLUSIONS}

1. The inclusion in the treatment protocol for CCI complex of drugs aimed at eliminating cholinergic deficien$\mathrm{cy}$, acetylcholinesterase inhibitors in combination with choline precursors, leads to the correction of cognitive impairment in chronic brain ischemia.

2. The statistically significant manifestations of the recovery of cognitive function (according to the MMSE scale) after the application of the developed complex therapy were associated mainly with a decrease in impulsivity due to an increase in the level of attention.

3. The statistically significant manifestations of a decrease in the level of anxiety-depressive disorders (according to the DASS-21 scale) after the application of the developed complex therapy were associated mainly with a decrease in anxiety due to the restoration of neurohumoral balance.

\section{REFERENCES}

1. Yevtushenko S.K. Distsirkulyatornaya entsefalopatiya kak anakhronizm otechestvennoy nevrologi [Discirculatory encephalopathy as an anachronism of the domestic neurology]. International Neurological Journal. 2010; 6(36): 22-31.(RU)

2. Petersen R.C., Caracciolo B., Brayne C. at al Mild cognitive impairment a concept in evolution. J Intern Med. 2014; 275 (3):214-28. doi 10.1111/ joim. 12190

3. Mankovsky N.B., S.M. Kuznetsova Vozrastnyye izmeneniya neyrotransmitternykhsistem mozga kakfaktor riskatserebrovaskulyarnoy patologii [Age-related changes in brain neurotransmitter systems as a risk factor for cerebrovascular pathology]. Journal of Neurology. B.M. Man'kovsky. 2013; 2:5-13.(UA)

4. EkushevaE.V.Kognitivnyyenarusheniya —aktual'naya mezhdistsiplinarnaya problema [Cognitive impairment is an active interdisciplinary problem]. Russian medical journal. 2018; 12 (1): 32-37.(RU)

5. Odinak M.M., Zhivolupov S.A, Panomarev V.V. at al Vosstanovleniye soznaniya kak proyavleniye neyroplastichnosti [Recovery of consciousness as a manifestation of neuroplasticity]. Questions of neurosurgery. 2014; 1:33-41.(RU)

6. Belenichev I.F., Cherniy V.I., Nagornaj E.A. et al. Neyroprotektsiya i neyroplastichnost' [Neuroprotection and neuroplasticity]. Kiev: Logos. 2015; 512.(RU)

7. Roohi-Azizi M., Arabzadeh S., Amidfar M., et al. Citicoline combination therapy for major depressive disorder: a randomized, double-blind, placebo-controlled trial. Clin Neuropharm. 2017; 40: 1-5.2885707

8. Odinak. M.M., Voznyuk I.A., Piradov M.A.et al Mnogotsentrovoye (pilotnoye) issledovaniye effektivnosti gliatilina pri ostrom ishemicheskom insul'te [Multicenter (first) study of the efficacy of gliatilin in acute ischemic stroke]. Annaly neurology. 2010; 1(4): 20-27.(RU)

9. Zakharov D.V., Mikhailov V.A. Rol' atsetilkholinovoy neyrotransmissii $v$ farmakoterapii kognitivnoy disfunktsii. [The role of acetylcholine neurotransmission in the pharmacotherapy of cognitive dysfunction]. Review of psychiatry and medical psychology. 2018; 3: 90-96.(RU)

10. Damulin I.V., Zhivolupov S.A., Zaitsev O.S.et al. Neyromidin v klinicheskoy praktike [Neuromidinein clinical practice]. M .: Medical Information Agency LLC; 2016, 64.(RU)

11. Zhivolupov C.A., Samartsev I.N, Syroezhkin F.A. Sovremennaya kontseptsiya neyroplastichnosti (teoreticheskiye aspekty i prakticheskaya znachimost') [The modern concept of neuroplasticity (theoretical aspects and practical significance)]. Journal of Neurology and Psychiatry. 2013; 10(113): 102-108.(RU)

12. Cherniy T.V., Andronova M.A.,Cherniy V.I. et al [The study of EEG predictors of neurotransmitter and neuroglial activity in patients with chronic cerebral ischemia]. Journal of Neurology V.I. Man'kovsky. 2017; 1(5): 15-23.(RU)

13. ESH/ESC guidelines for the management of arterial hypertension: the Task Force for the Management of Arterial Hypertension of the European Society of Hypertension (ESH) and of the European Society of Cardiology (ESC). Eur Heart J. 2013; 34: 2159-2219,

14. Pro zatverdzhennya ta vprovadzhennya medyko-tekhnolohichnykh dokumentiv zi standartyzatsiyi medychnoyi dopomohy pry arterial'niy hipertenziyi: nakaz MOZ Ukrayiny № 384 vid 24.05.2012 [About statement and introduction of medical and technological documents on standardization of medical care in hypertension: order of the Ministry of Health of Ukraine]. №384 of 24.05.2012 Available from: http://moz. gov.ua/en/portal/dn_20120524_384.htm (UA) 
15. Lyakh Y.E., Guryanov V. G., Khomenko V. N.et al Osnovy komp'yuternoy biostatistiki: analiz informatsii v biologii, meditsine i farmatsii statisticheskim paketom MedStst [Fundamentals of computer biostatistics: analysis of information in biology, medicine and pharmacy with the statistical package MedStst.]. D.: Papakitsa E.K. 2016;214.(RU)

16. Orlova E. A., Kolesnik T.N. Klinicheskaya psikhologiya [Clinical Psychology]. M.:Yurayt. 2014; 368. (RU)

17. Rachin, A. P., Mikhailova E.V. Depressivnyye i trevozhnyye rasstroystva [Depressive and anxiety disorders]. M.: GEOTAR-Media. 2016; 106.(RU)

18. Peterson R.C., Lopez 0., Armstrong M.J. et al Kratkoye izlozheniye prakticheskikh rekomendatsiy: Legkiye kognitivnyye narusheniya. Otchet Podkomiteta po razrabotke, rasprostraneniyu i vnedreniyu rukovodyashchikh printsipov Amerikanskoy akademii nevrologii. [Practice guidline update summary: Mild cognitive impairment. Report of the Guideline Development, Dissemination, and Implementation Subcommittee of the American Academy of Neurology]. Neurology. 2018;90(3):126-135. doi: 10.1212/WNL.0000000000004826
Name of the individual research work: "Pathogenetic role of arterial hypertension and coronary heart disease in the formation of Chronic Cerebral Ischemia in public servants" of State Scientific Institution "Scientific and Practical Center for Preventive and Clinical Medicine" of the State Administrative Department, Kyiv, Ukraine.

\section{ORCID and contributionship:}

Tatiana V. Chernii - 0000-0002-0095-6091 ${ }^{A, B, C, D, E, F}$

\section{Conflict of interest:}

The Author declare no conflict of interest.

\section{CORRESPONDING AUTHOR Tatiana V. Chernii \\ St. Verchnja, 5, 01014, Kyiv, Ukrainy \\ tel: +380505771337 \\ e-mail:Tatiana.cherniy@gmail.com}

Received: 22.01 .2020

Accepted: 31.03 .2020

\footnotetext{
A - Work concept and design, B - Data collection and analysis, C - Responsibility for statistical analysis,
} D - Writing the article, $\mathbf{E}$-Critical review, $\mathbf{F}$ - Final approval of the article 